\title{
Perancangan Aplikasi Web Dengan Akses Mobile Untuk Sistem Informasi Penjualan Menggunakan Arsitektur MVC (Studi Kasus : Toko Pacific Motor Bukittinggi)
}

\author{
Ricky Akbar ${ }^{1 *}$, M Herizki Hamdani 2 \\ 1,2) Jurusan Sistem Informasi Fakultas Teknologi Informasi Universitas Andalas \\ (corresponding author) rickyakbar1984@gmail.com *, herizki.hamdani@gmail.com
}

\begin{abstract}
The daily undergoing business process of purchasing, inventory, and selling of goods at Pacific Motor Bukittinggi shop is still manually executed and not being favour in computerized. It trigerred some problems including a build up of archives and reports, long counting process transactions, the availability of current stock items and accumulation report sales and purchases. To solve these matters, designing Web Applications with Mobile Access on Pacific Motor Toko Bukittinggi is necessary in order to create more effective business processes, as well as for the updated information accesibility for management through mobile devices. The methodology used in this design is the waterfall method. The implementation process are, (1) the analysis of the system requirements by conducting a preliminary study and data collection based on field studies and literature, (2) the design of the system by using diagrams or architectural applications such as Business Process Model Notation (BPMN), use case diagrams, sequence diagrams, class diagrams, and Entity Relationship Diagram (ERD), (3) the implementation of a system using OOP (Object Oriented programming), software architecture MVC (Model, View, Controller) and using the PHP programming language and PostgreSQL Database, (4) testing the system using the method of blackbox testing. The design process has been successfully performed until the testing phase and run as needed
\end{abstract}

Keyword: Selling, Purchasing, Web, Mobile, MVC, Information System

Abstrak - Proses bisnis pembelian, stok, dan penjualan barang yang sedang berlangsung pada toko Pacific Motor Bukittinggi masih dilakukan secara manual dan belum terkomputerisasi. Hal ini menyebabkan terjadinya beberapa masalah antara lain penumpukan arsip dan laporan, proses penghitungan transaksi yang lama, lambatnya ketersediaan informasi terhadap stok barang dan rekap laporan penjualan maupun pembelian yang sulit. Untuk mengatasi masalah ini, perancangan Aplikasi Web dengan Akses Mobile pada Toko Pacific Motor Bukittinggi ini sangat dibutuhkan agar proses bisnis penjualan, stok, dan pembelian barang dapat dilakukan secara efektif dan efisien, serta bagi pimpinan dapat mengakasesnya dimanapun dan kapanpun dia butuhkan dengan Smartphone-nya. Adapun metodologi yang digunakan dalam perancangan ini adalah metode waterfall. Proses pelaksanaan dari metode waterfall yang digunakan ini, yaitu (1) analisis kebutuhan sistem dengan melakukan studi pendahuluan dan pengumpulan data berdasarkan studi lapangan dan studi pustaka, (2) perancangan sistem dengan menggunakan diagram ataupun arsitektur aplikasi seperti Business Process Model Notation (BPMN), use case diagram, sequence diagram, class diagram, dan Entity Relationship Diagram (ERD), (3) implemetasi sistem menggunakan konsep OOP(Object Oriented Programming) dan arsitektur perangkat lunak MVC (Model, View, Controller) serta menggunakan bahasa pemrograman PHP dan database PostgreSQL, (4) melakukan pengujian sistem dengan menggunakan metode blackbox testing. Proses perancangan ini telah berhasil dilakukan hingga tahap pengujian dan berjalan sesuai kebutuhan.

Kata Kunci- Penjualan, Pembelian, Web, Mobile, MVC, Sistem Informasi.

\section{PENDAHULUAN}

Toko Pacific Motor merupakan salah satu perusahaan yang bergerak di bidang penjualan sparepart dan accesories dari berbagai mobil. Penjualan dan pemesanan barang merupakan sebagian dari aktivitas proses bisnis di toko Pacific Motor. Mengembangkan dan mengelola sistem informasi dengan baik akan mampu menjadikan perusahaan berkembang. Sistem pemesanan, penjualan, penyimpanan dilakukan belum sepenuhnya menggunakan sistem yang terkomputerisasi dalam pengolahan data barang. Masih terdapat kekurangan dalam pengelolaan data transaksi di toko Pacific Motor, seperti terjadinya penumpukan arsip dan belum tersedianya tempat penyimpanan arsip membuat keamanan datanya kurang terjamin. Kekurangan lainnya dalam proses transaksi yakni pembuatan laporan transaksi, pelayanan transaksi, dan pencarian data yang lambat, penghitungan data dalam jumlah banyak akan sulit dilakukan dan pengelolaan barang masuk serta keluar juga kurang terkendali sehingga akan menimbulkan permasalahan dalam administrasi toko.

Salah satu solusi yang dapat dilakukan untuk mengatasi permasalahan dari toko Pacific Motor adalah dengan memanfaatkan perkembangan teknologi informasi. Dunia bisnis memanfaatkan teknologi informasi terutama dalam area pengolahan data sehingga dapat menghasilkan informasi sebagai alat bantu pengambilan keputusan bisnis, baik yang bersifat strategis ataupun operasional. Pada awal penggunaan TI sebagai perangkat bantu pengolahan data, sering muncul 
istilah Electronic Data Processing (EDP). Perkembangan lebih lanjut dari penggunaan teknologi informasi dalam sistem informasi sering pula disebut dengan sistem informasi berbasis komputer (Computer-Based Information System/CBIS) [1]. Teknologi informasi yang akan menjadi solusi bisnis toko Pacific Motor adalah Aplikasi web dengan akses mobile untuk Sistem Informasi Penjualan Retail dengan menggunakan arsitektur MVC (Model, View, Controller).

Perkembangan dunia mobile kini berada di tahap kedewasaan. Pengguna perangkat mobile hingga akhir tahun 2006 di Asia telah mencapai 300 juta pengguna. Hal yang lebih mencengangkan, Indonesia adalah salah satu konsumen terbesar untuk perangkat mobile. Pada perkembangan tersebut, unsur mobilitas menjadi disukai masyarakat, terutama pada segmen masyarakat bisnis yang memang dalam pekerjaan sehari-harinya bekerja tanpa batasan waktu dan tempat [2]. Pemilik dari toko Pacific Motor yang memang seringkali berada di luar toko mendapatkan kemudahan dengan adanya mobile phone yang dimiliki dan terhubung langsung dengan transaksi di toko sehingga bisa di cek kegiatan transaksi tanpa harus ada di toko. Oleh karena itu, dirancang sebuah sistem informasi berbasis web dengan akses mobile pada toko Pacific Motor Bukittinggi.

\section{PEMODELAN WATERFALL}

Model pengembangan yang digunakan dalam pembangunan perangkat lunak ini adalah metode waterfall. Metode waterfall adalah suatu proses pengembangan perangkat lunak berurutan, di mana kemajuan dipandang sebagai terus mengalir ke bawah (seperti air terjun) melewati fase-fase perencanaan, pemodelan, implementasi (konstruksi), dan pengujian [3]. Gambar 1 berikut ini adalah gambar pemodelan waterfall.

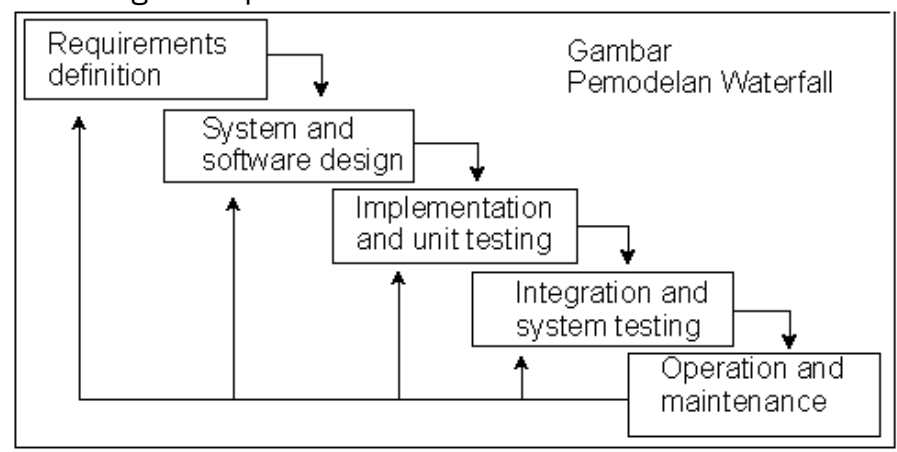

Gambar 1. Pemodelan Waterfall [3]

\section{A. Analisis Kebutuhan Sistem}

Tahap analisis diawali dengan gambaran berupa studi pendahuluan dan pengumpulan data di toko Pacific Motor. Setelah itu dilakukan analisis terhadap sistem transaksi penjualan yang berjalan, kebutuhan yang diinginkan dan diperlukan oleh pengguna serta masalah yang akan diselesaikan. Analisis ini mencakup proses bisnis perusahaan yang digambarkan menggunakan BPMN (Bussiness Process Model Notation), use case, sequence diagram, use case scenario, dan class analysis.

\section{B. Perancangan Sistem}

Tahapan perancangan sistem dilakukan dengan membuat diagram yang dibutuhkan seperti ERD (entity relationship diagram), arsitektur aplikasi, statechart diagram dilakukan untuk mobile dan class diagram. Kemudian dilakukan perancangan terhadap user interface untuk sistem informasi berbasis web dan mobile.

\section{Implementasi Sistem}

Tahap ini merupakan implementasi yang dilakukan dengan menggunakan konsep OOP (object oriented programming) kemudian menggunakan arsitektur perangkat lunak MVC (Model, View, Controller). Bahasa yang digunakan yaitu bahasa pemograman PHP dan JavaScript sedangkan untuk tampilan menggunakan HTML5 kemudian database menggunakan PostgreSQL.

\section{Pengujian Sistem}

Tahapan pengujian sistem dilakukan dengan menggunakan metode blackbox testing serta pengujian dilakukan secara terprogram dan pengujian secara manual. Pengujian aplikasi mobile dilakukan hanya pada sistem operasi android sedangkan pengujian aplikasi web dilakukan pada perangkat komputer dengan sistem operasi windows

\section{ANALISIS DAN PERANCANGAN SISTEM}


Pada tahap analisis dan perancangan sistem digunakan UML (Unified Modeling Language) yang berfungsi untuk menggambarkan prosedur dan proses kerja aplikasi.[4]

A. Analisis Sistem

1) BPMN Penjualan Barang : Pada penjualan barang semua aktivitas masih dilakukan secara manual. Untuk pencatatan penjualan harian maupun laporan penjualan masih belum terbukukan secara tepat dan akurat. Berdasarkan hasil analisis dari tahap penjualan barang maka untuk tahapan proses penjualan barang yang sedang berjalan adalah sebagai berikut :

1. Pembeli menanyakan barang ke toko dan karyawan gudang memeriksa ketersediaan barang.

2. Karyawan gudang menunjukkan barang ke pembeli.

3. Jika barang cocok maka karyawan gudang membuat faktur penjualan dan pembeli membayar sesuai jumlah faktur penjualan.

BPMN untuk proses penjualan barang yang sedang berjalan dapat dilihat pada gambar 2

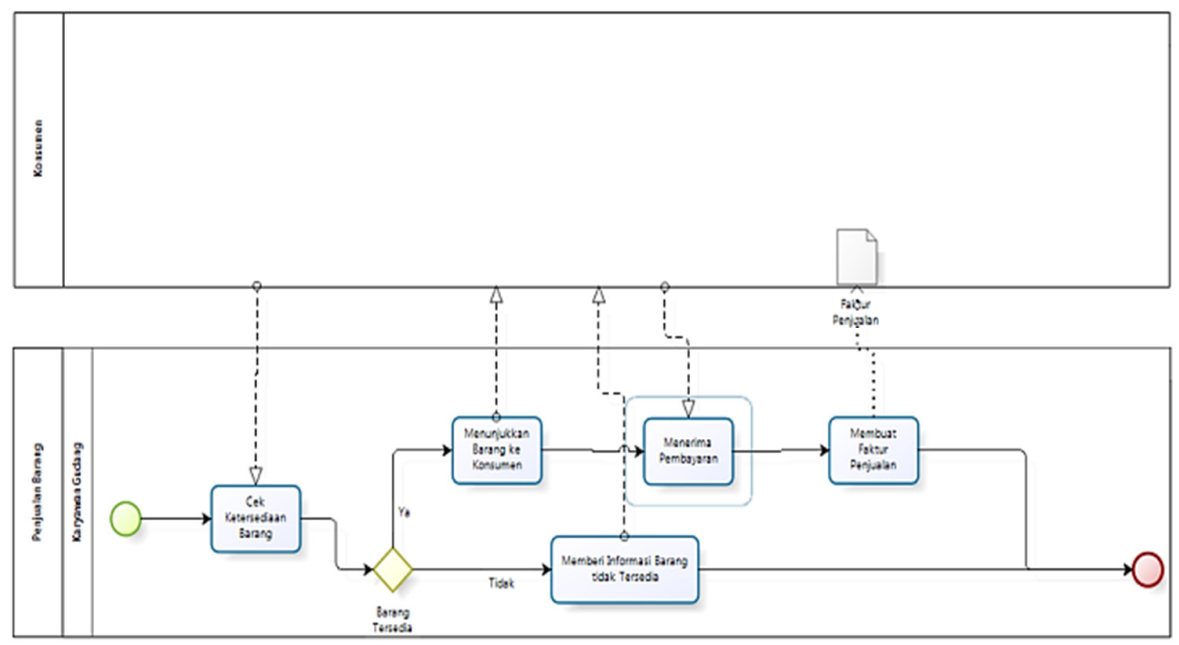

Gambar 2. BPMN Penjualan Saat Ini

Dari hasil analisis proses penjualan barang saat ini dibuatlah proses usulan dengan memanfaatkan sistem informasi penjualan baru yang menggunakan database sebagai penyimpanan dari penjualan harian dengan tahapan proses sebagai berikut :

1. Pembeli menanyakan barang ke toko dan karyawan gudang memeriksa ketersediaan barang dari aplikasi.

2. Karyawan gudang menunjukkan barang ke pembeli.

3. Jika barang cocok maka karyawan kasir memasukkan data penjualan ke aplikasi, setelah itu aplikasi mencetak faktur sesuai informasi data input penjualan dan pembeli membayar sesuai jumlah faktur penjualan.

BPMN untuk proses penjualan barang yang diusulkan dapat dilihat pada gambar 3

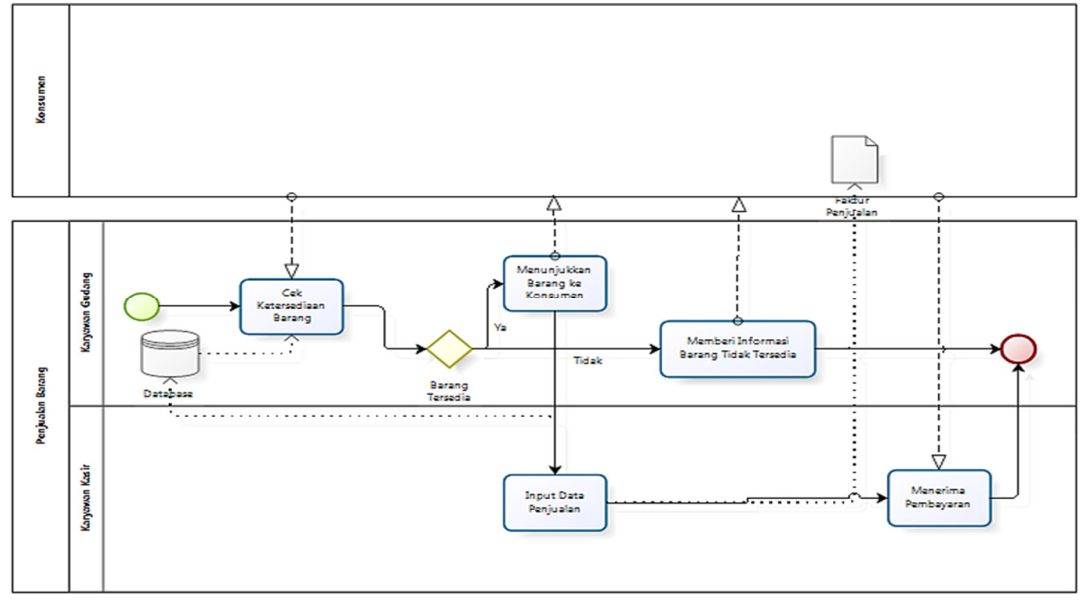

Gambar 3. BPMN Penjualan Usulan 
2) Use Case Diagram: Kegiatan yang bisa dilakukan oleh pengguna terhadap sistem dan sistem bisa menanggapi permintaan dari pengguna [7]. Use case diagram dalam pembangunan sistem ini terdiri dari 3 aktor dan 28 fungsional. Gambar 4 merupakan aktivitas yang digambarkan ke dalam use case diagram.

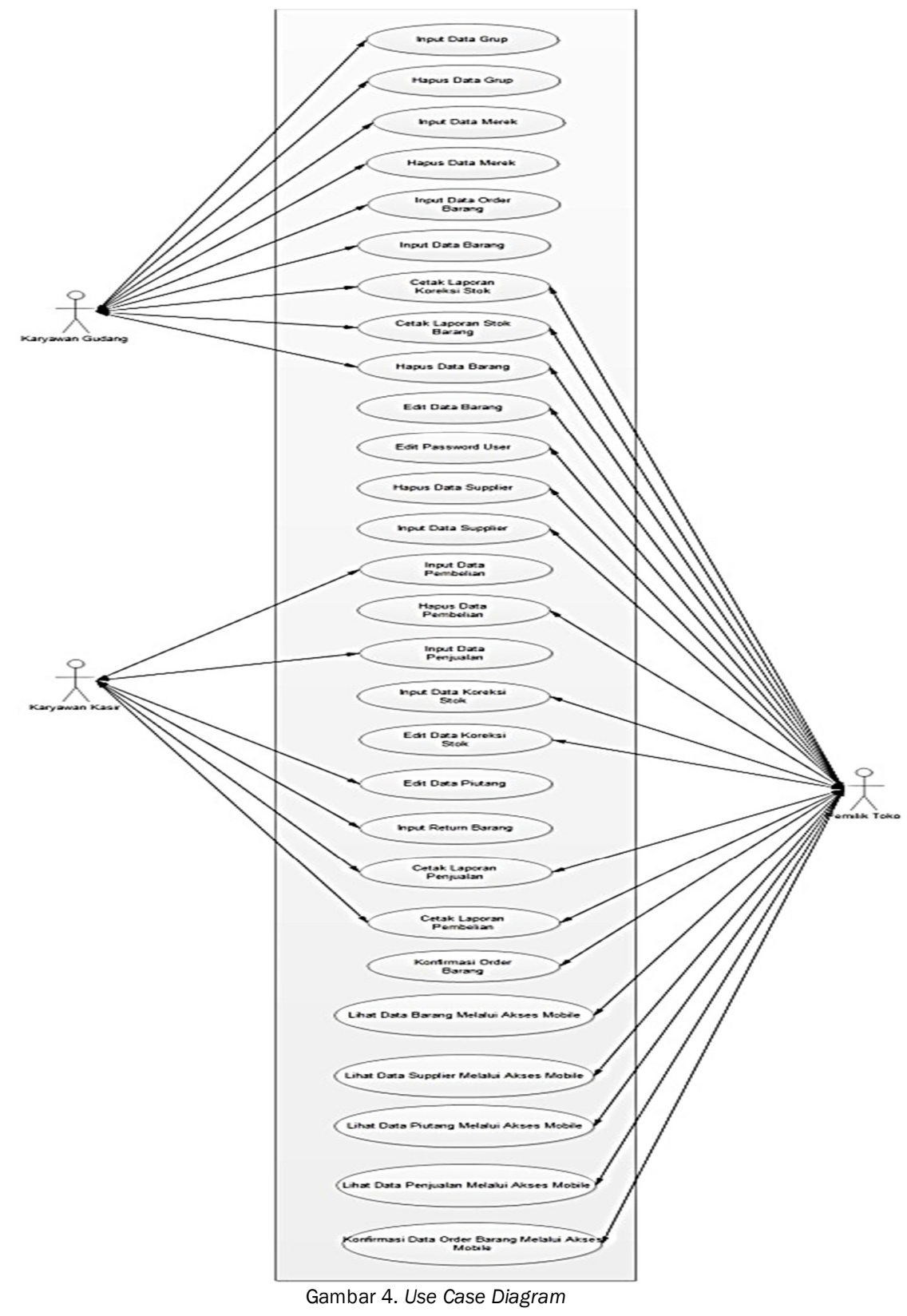

3) Skenario Use Case Input Data Penjualan :Use case input data penjualan dapat dilakukan oleh karyawan kasir toko. Pada form penjualan karyawan kasir akan memasukkan data barang yang dibeli oleh konsumen. Skenario use case untuk input data penjualan dapat dilihat pada tabel 1 
TABEL I SKENARIO USE CASE INPUT DATA BARANG

\begin{tabular}{|l|l|}
\hline Use Case Name & Input Data Barang \\
\hline $\begin{array}{l}\text { Participating } \\
\text { actors }\end{array}$ & Karyawan Gudang \\
\hline Flow of events & $\begin{array}{l}\text { 1. Karyawan gudang meng-klik } \\
\text { menu data barang } \\
\text { 2. Sistem malaman data barang } \\
\text { halkan } \\
\text { Aktor mengklik tombol } \\
\text { tambah data barang } \\
\text { 4. Sistem Menampilkan form } \\
\text { 3. input data barang } \\
\text { 3aryawan gudang mengisi form } \\
\text { input data barang } \\
\text { 6. Sistem menyimpan dan } \\
\text { menampilkan data barang }\end{array}$ \\
\hline Entry condition & Aktor telah login ke sistem \\
\hline Exit condition & Sistem menyimpan data \\
\hline
\end{tabular}

4) Sequence Diagram Input Data Penjualan : Aktor yang terlibat dalam proses input data penjualan adalah karyawan/kasir toko. Proses input data penjualan dikelola oleh transaksi controller dan disimpan dalam entitas penjualan dan detail penjualan. Sequence diagram untuk proses input data penjualan dapat dilihat pada gambar 5

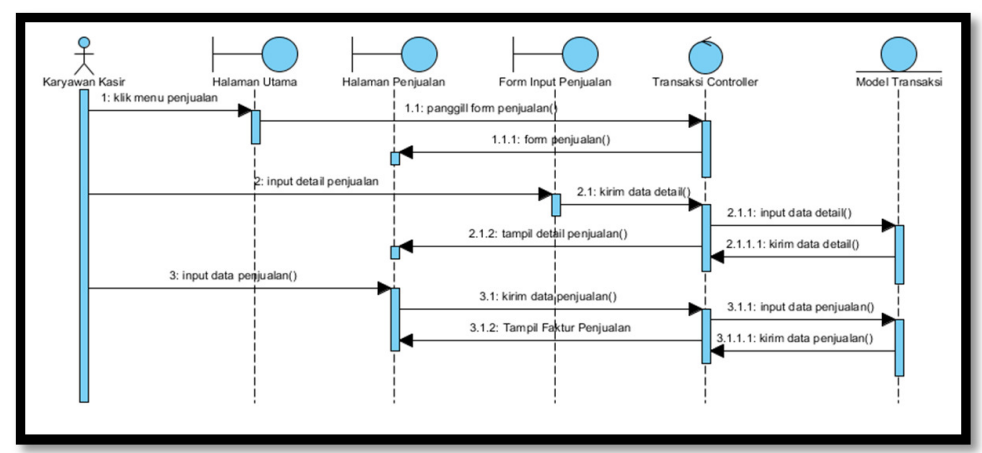

Gambar 5. Sequence Diagram Penjualan.

5) Class Analysis Input Data Penjualan : Class analysis untuk input data penjualan terdiri dari 3 interface yaitu halaman utama, halaman penjualan, form input detail penjualan. Input data penjualan dikelola oleh transaksi controller dimana model transaksi bertindak sebagai model. Analisis kelas untuk input data penjualan dapat dilihat pada gambar6

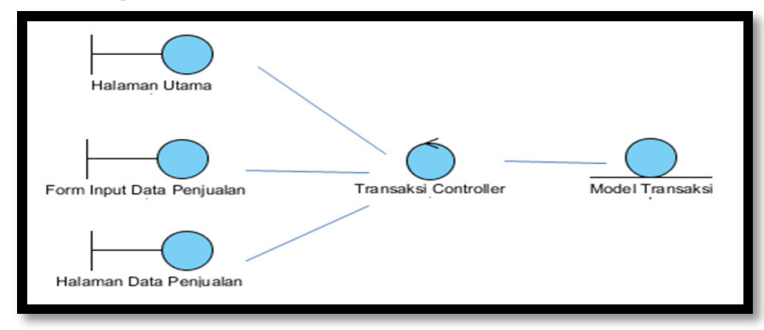

Gambar 6. Class Analysis Input Data Penjualan

B. Perancangan Sistem

1) Entity Relationship Diagram: merupakan teknik yang digunakan untuk memodelkan kebutuhan data dari suatu organisasi, biasanya oleh System Analyst dalam tahap analisis persyaratan proyek pengembangan sistem [9]. Pada tahap ini ERD terbentuk dari 14 tabel yang saling berelasi satu dengan yang lainnya, seperti yang terlihat pada gambar 7. 


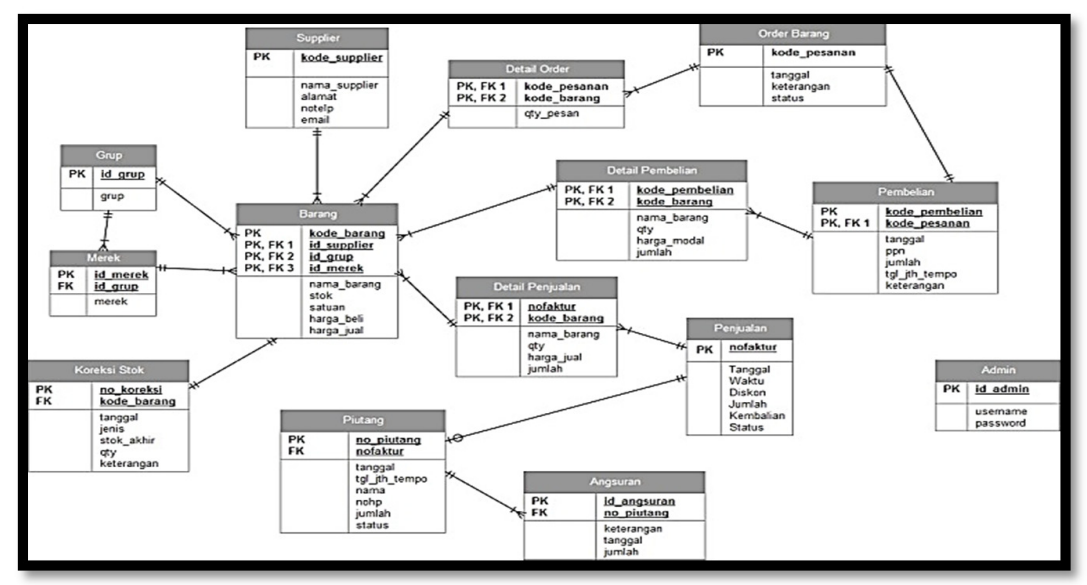

Gambar 7. Entitiy Relationship Diagram

2) Struktur Basis Data Tabel Penjualan : Berikut merupakan gambaran struktur basis data yang akan diimplementasikan ke dalam tabel penjualan yang terlihat pada tabel 2.

TABEL II STRUKTUR BASIS DATA TABEL PENJUALAN

\begin{tabular}{|l|l|l|l|}
\hline Nama Atribute & Tipe Data & Ukuran & Keterangan \\
\hline nofaktur & integer & - & $\begin{array}{l}\text { Primary } \\
\text { Key }\end{array}$ \\
\hline tanggal & date & - & \\
\hline waktu & time & - & \\
\hline diskon & integer & - & \\
\hline jumlah & integer & - & \\
\hline kembalian & integer & - & \\
\hline status & $\begin{array}{l}\text { character } \\
\text { varying }\end{array}$ & 20 & \\
\hline
\end{tabular}

3) Arsitektur Perangkat Lunak: MVC merupakan arsitektur perangkat lunak yang digunakan untuk memudahkan pengelolaan pengembangan aplikasi. Aplikasi yang semula ditulis dalam satu halaman, dipisah-pisahkan menjadi tiga bagian yang saling berhubungan. Bagian-bagian itu adalah Model, View, dan Controller [5].

Gambar 8 merupakan arsitektur perangkat lunak MVC yang menunjukkan view meminta data ke controller. Kemudian controller memanggil data ke model. Setelah itu model mengirimkan data yang diminta view ke controller. Kemudian controller mengirim data ke view, sehingga dapat dilihat bahwa controller berguna untuk penghubung antara view dan model. Pada studi kasus di Pacific Motor ini Class Controller yang di rancang ada 4 yaitu: TransaksiController, PagesController, MasterController dan ReportController. Sementara itu untuk Class Model ada 4 juga yaitu: ModelTransaksi, ModelPages, ModelReport dan ModelMaster. Pada bagian view tidak memiliki class.

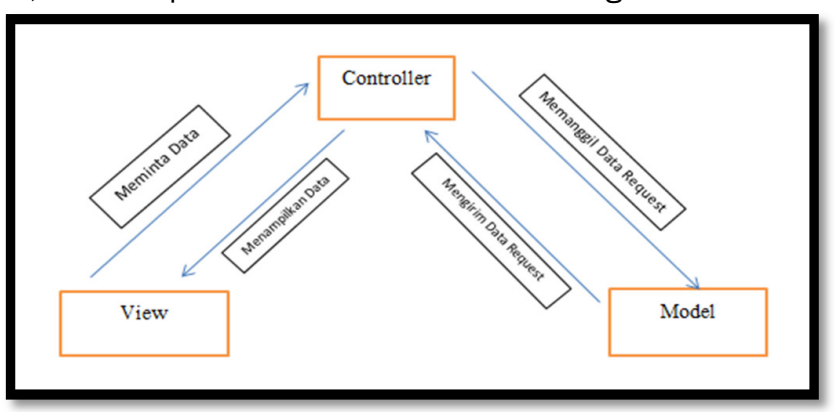

Gambar 8. Arsitektur Perangkat Lunak

4) Statechart Diagram: Statechart diagram adalah sebuah teknik yang sering digunakan untuk menggambarkan behaviour sebuah sistem. Statechart diagram menggambarkan transisi dan perubahan keadaan (dari satu state ke state yang lain) suatu objek pada sistem sebagai akibat dari stimuli yang diterima [6]. Dalam pembangunan aplikasi ini 
dilakukan perancangan statechart diagram untuk aplikasi mobile. Rancangan statechart diagram untuk aplikasi mobile dapat dilihat pada gambar 9.

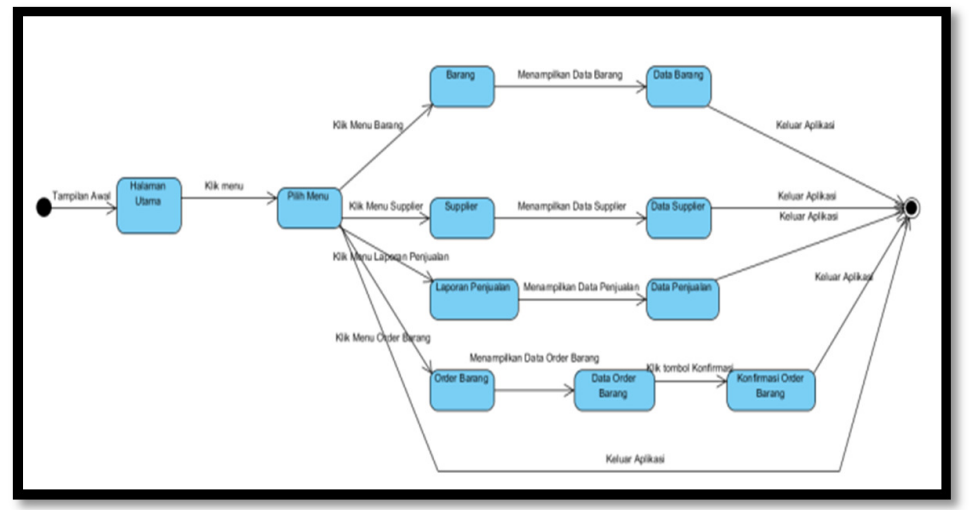

Gambar 9. Statechart Diagram

5) Class Diagram : Class diagram merupakan suatu gambaran class-class yang dimasukkan ke dalam aplikasi [8]. Class diagram yang digunakan dalam aplikasi ini hanya class controller dan class model sedangkan pada bagian view tidak memiliki class. Untuk lebih jelasnya dapat dilihat pada gambar 10.

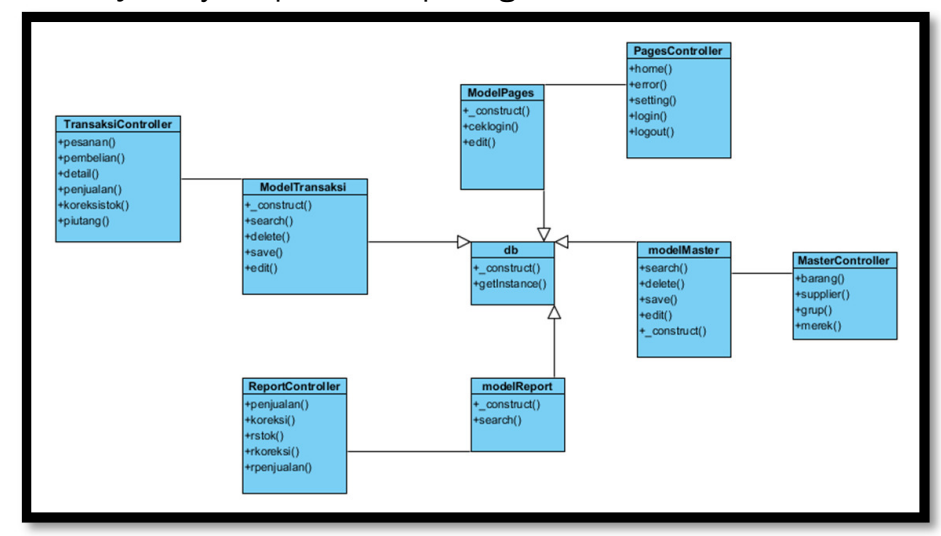

Gambar 10. Class Diagram

6) User Interface Halaman Home: Pada tampilan halaman home terdapat header, footer, dan beberapa menu utama yang ada pada aplikasi seperti terlihat pada gambar 12.

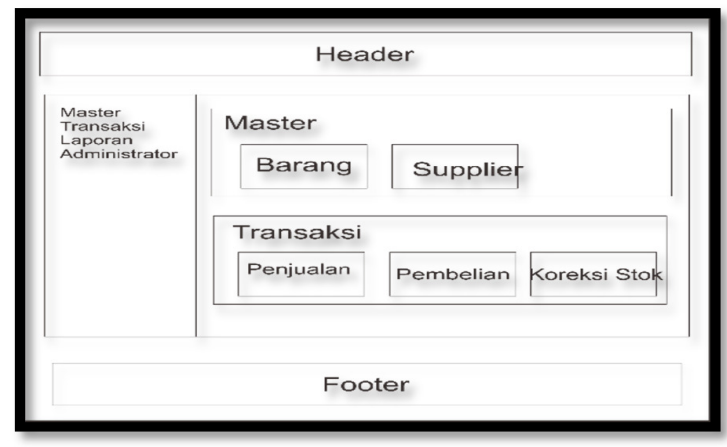

Gambar 11. Form Login

\section{IMPLEMENTASI DAN PENGUJIAN}

A. Implementasi

1) Batasan Implementasi : Batasan implementasi yang dibangun pada aplikasi sistem informasi penjualan retail berbasis web dengan fitur mobile di toko Pacific Motor Bukittinggi yaitu :

a. Bahasa pemrograman yang digunakan dalam aplikasi ini yaitu bahasa pemrograman PHP, javascript, dan ajax serta untuk tampilan menggunakan HTML5. 
b. Database yang digunakan dalam implementasi aplikasi yaitu database PostgreSQL.

c. Tema yang digunakan dalam aplikasi web menggunakan Bootstrap css.

d. Pembangunan perangkat lunak dilakukan dengan menggunakan konsep OOP (Object Oriented Programming) dengan arsitektur perangkat lunak MVC (Model, View, Controller).

2) Pengkodean Program : Setelah melakukan analisis dan perancangan, maka langkah selanjutnya adalah melakukan pengkodean program dengan menggunakan bahasa pemrograman yang telah ditentukan sebelumnya. Disini diuraikan mengenai kode program yang digunakan untuk implementasi aplikasi berbasis web. Berikut ini contoh pengkodean program pada script Class Model untuk proses login seperti program 1.

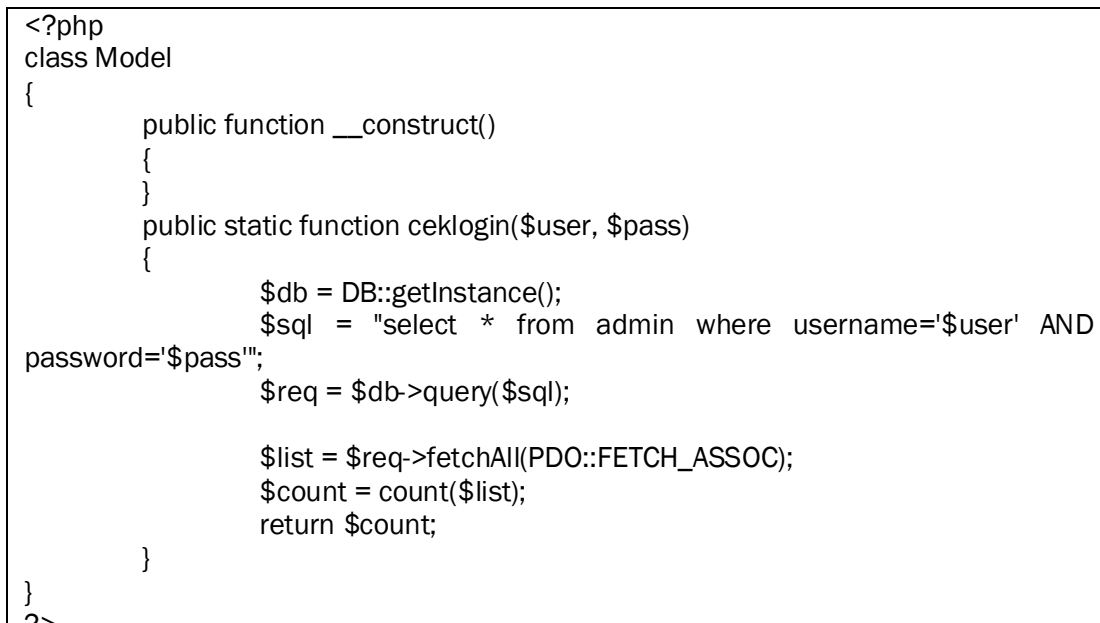

Program 1 Script Class Model

3) Implementasi Antar Muka : Implementasi antar muka menggambarkan tampilan dari aplikasi yang dibangun mencakup antar muka aplikasi web maupun aplikasi mobile. Implementasi dari aplikasi terdiri dari beberapa halaman yang ditampilkan sesuai dengan menu yang dipilih oleh user. Berikut contoh implementasi antar muka halaman home aplikasi web yang telah dibangun seperti pada gambar 12.

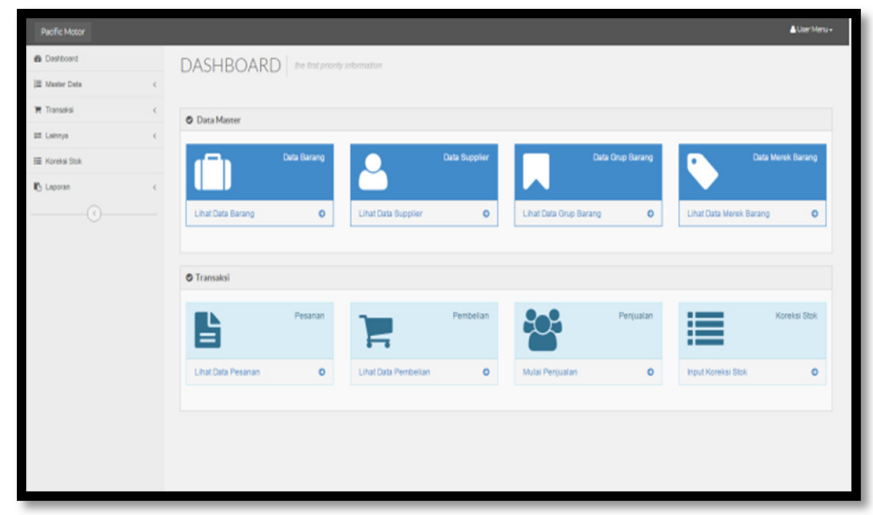

Gambar 12. Halaman Home Aplikasi Web

B. Pengujian

1) Kasus dan Hasil Pengujian : Bagian ini menjelaskan mengenai kasus serta hasil pengujian yang dilakukan. Pengujian dilakukan berdasarkan fokus pengujian yang dipaparkan sebelumnya. Berikut ini merupakan contoh dari hasil pengujian pada proses input data barang.

Pengujian dilakukan dalam 2 kondisi yaitu kondisi sukses dan kondisi gagal, dimana untuk kondisi gagal terdeteksi apabila ada barang yang diinputkan dengan kode yang sama dengan barang yang diinputkan sebelumnya. Hasil pengujian dapat dilihat pada tabel 3. 
TABEL III PENGUJIAN INPUT DATA BARANG

\begin{tabular}{|l|l|}
\hline \multicolumn{2}{|l|}{ Kasus dan Hasil Uji (Sukses) } \\
\hline Input Data Barang & Data Lengkap Barang \\
\hline Data Masukan & $\begin{array}{l}\text { Data tersimpan dan muncul } \\
\text { notifikasi sukses }\end{array}$ \\
\hline Yang diharapkan & $\begin{array}{l}\text { Data tersimpan dan sistem } \\
\text { memunculkan notifikasi sukses }\end{array}$ \\
\hline Pengamatan & Diterima \\
\hline Kesimpulan & $\begin{array}{l}\text { Data kode barang sudah ada di } \\
\text { dalam database }\end{array}$ \\
\hline Kasus dan Hasil Uji (Gagal) \\
\hline Input Data Barang & $\begin{array}{l}\text { Data tidak tersimpan dan muncul } \\
\text { pemberitahuan }\end{array}$ \\
\hline Data Masukan & $\begin{array}{l}\text { Data barang tidak disimpan dan } \\
\text { muncul pemberitahuan }\end{array}$ \\
\hline Yang diharapkan & Diterima \\
\hline Pengamatan
\end{tabular}

a. Pengujian Input Data Barang (Sukses)

Pada pengujian input data barang dalam kondisi sukses dilakukan dengan menggunakan aplikasi yang telah dibuat. Karyawan gudang menginputkan data barang di form input data barang yang telah disediakan. Jika data berhasil diinputkan maka sistem akan mengeluarkan notifikasi bahwa data berhasil diinputkan dan data yang masuk akan tampil di tabel data barang seperti pada gambar 13.

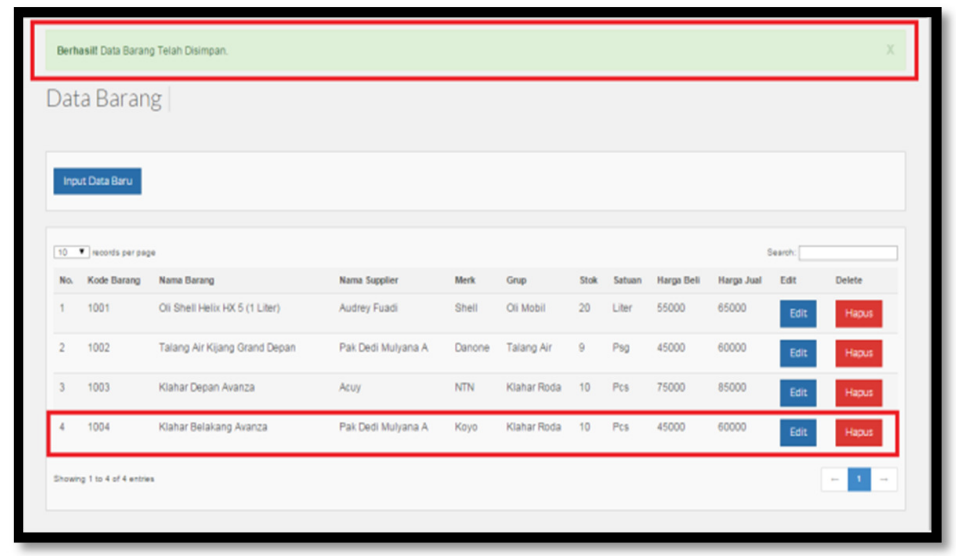

Gambar 13. Notifikasi Sukses Input Data Barang

Untuk melakukan pembuktian bahwa data sudah diinputkan sesuai dengan keinginan, maka dilakukan pengecekan lewat database dan melakukan query select dengan field kode barang yang diinputkan sebelumnya. Pembuktian ini dapat dilihat pada gambar 14.

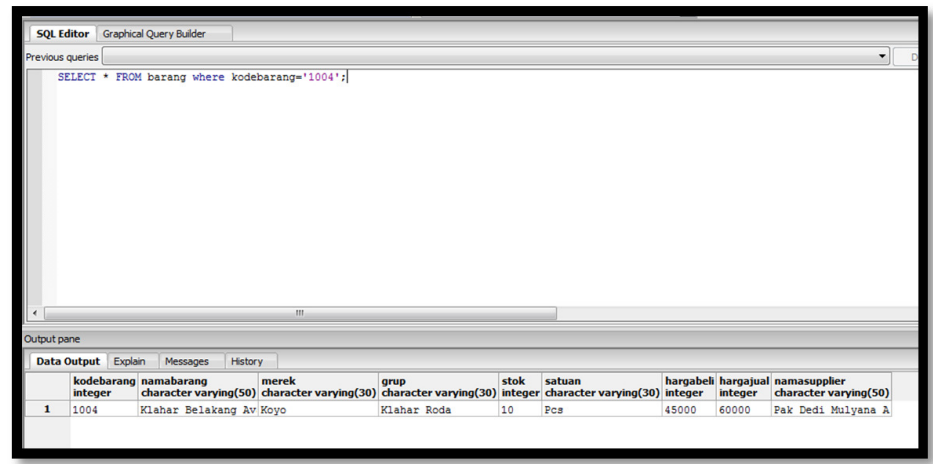

Gambar 14. Select Data Input di Database 
b. Pengujian Input Data Barang (Gagal)

Input data barang dengan kondisi gagal apabila kode barang yang dimasukkan telah terdaftar sebelumnya di dalam database sehingga tidak diperbolehkan. Contoh notifikasi sistem dan pengujian jika input data barang dengan kondisi gagal dapat dilihat pada gambar 15.

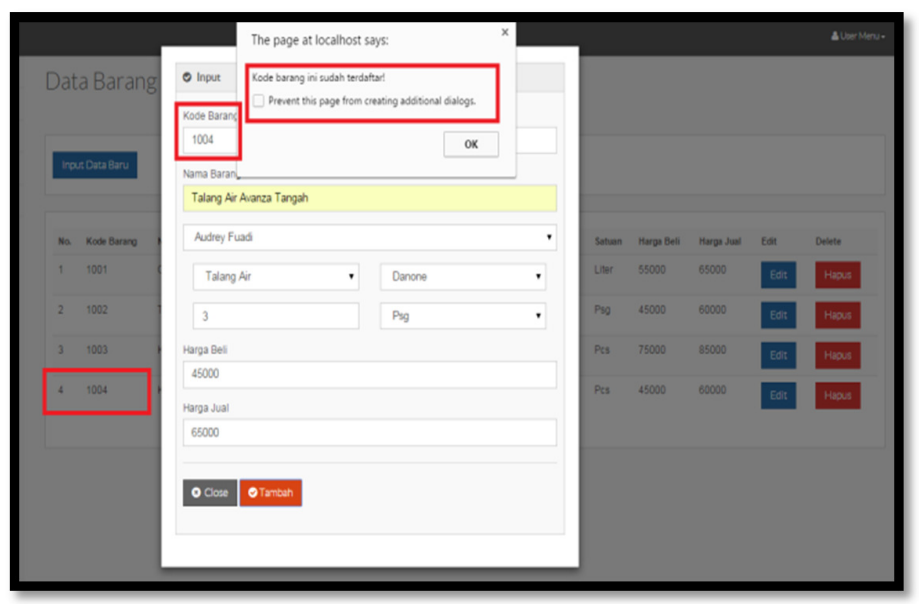

Gambar 15. Pengujian Input Data Barang Kondisi Gagal

Untuk melakukan pembuktian bahwa data yang diinputkan tidak masuk ke dalam database maka dilakukan pencarian data di database berdasarkan nama barang yang gagal dimasukkan sebelumnya. Contoh pembuktian dapat dilihat pada gambar 16.

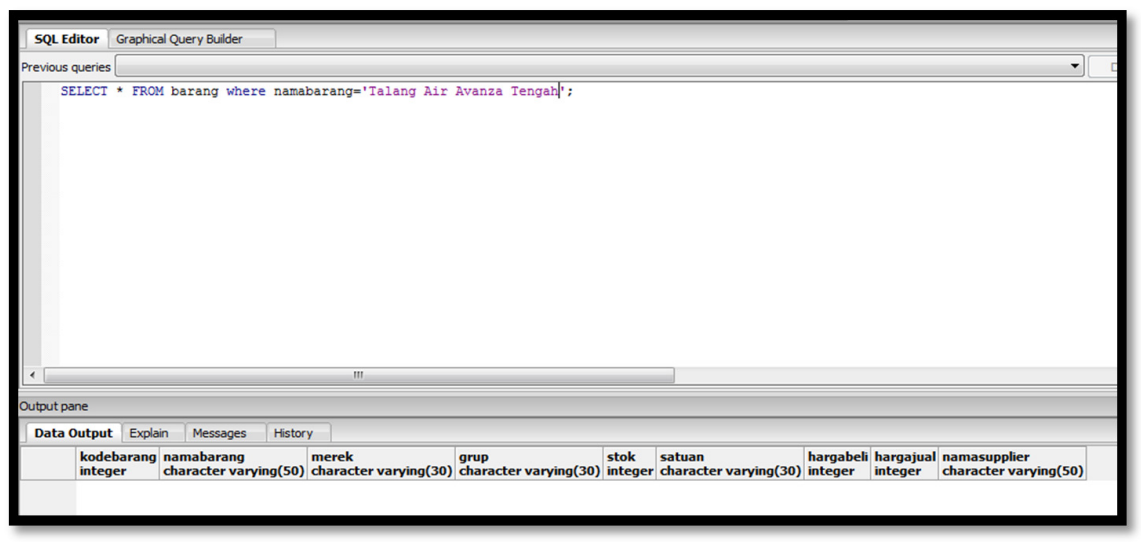

Gambar 16. Pengecekan Database Input Data Barang Kondisi Gagal

2) Laporan yang dihasilkan oleh aplikasi

Laporan yang dihasilkan oleh aplikasi yaitu laporan data stok barang, laporan transaksi penjualan, pembelian dan Laba Rugi. Namun laporan ini bisa ditambahkan sesuai dengan kebutuhan dari perusahaan. Gambar 17 merupakan contoh dari laporan penjualan.

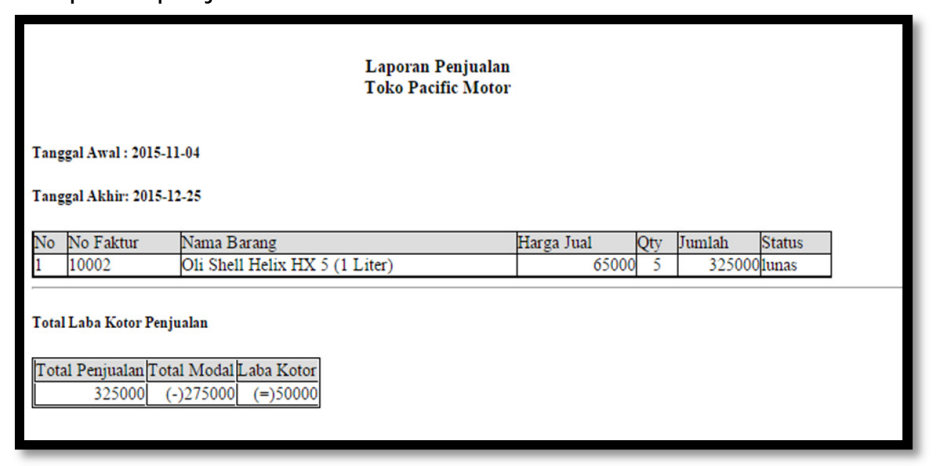

Gambar 17. Tampilan Laporan Penjualan 
3) Akses Mobile

Untuk memudahkan akses pemilik toko terhadap segala transaksi yang terjadi, maka apikasi juga dirancang dengan akses mobile, agar pemilik toko dapat melihat perkembangan atau transaksi yang terjadi di perusahaan dimana pun dan kapanpun dia membutukan. Aplikasi mobile merupakan sebuah aplikasi yang memungkinkan kita untuk dapat melakukan berbagai aktifitas dengan menggunakan perangkat mobile [10]. Karena pemilik toko biasanya jarang sekali menetap di toko. Dengan adanya akses via aplikasi mobile ini tentunya sangat bermanfaat sekali bagi pemilik perusahaan. Gambar 18 dibawah adalah salah satu contoh bentuk aplikasi mobile dari sistem informasi penjualan yang dibangun. Pada aplikasi tersebut data yang ditampilkan adalah tanggal transaksi, nomor faktur, nama barang dan harga jual. Jika datanya banyak user bisa mencari data yang dibutuhkan dengan cepat di menu search dengan mengetikan nomor faktur atau nama barang.

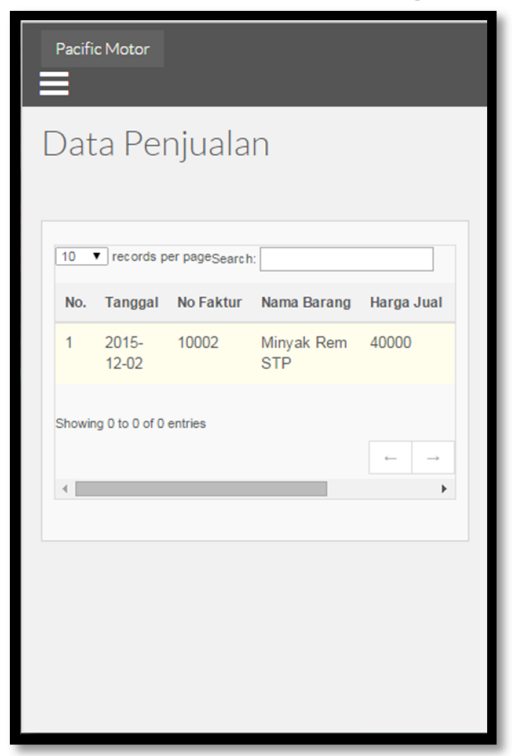

Gambar 18. Tampilan Data Penjualan Via Mobile

\section{PENUTUP}

Dalam pengembangan sistem ini mulai dari tahap analisis, perancangan, hingga tahap implementasi dan pengujian dapat diambil kesimpulan bahwa perancangan aplikasi web dengan akses mobile untuk sistem informasi penjualan retail menggunakan arsitektur MVC di Toko Pacific Motor Bukittinggi telah berhasil dan sesuai dengan fungsional yang diinginkan seperti uraian berikut :

1. Proses bisnis yang terjadi pada toko Pacific Motor Bukittinggi saat ini, yaitu penjualan, pembelian, return barang, dan koreksi stok barang masih dilakukan secara manual tanpa adanya sistem yang terkomputerisasi.

2. Tahapan analisis dan perancangan yang digunakan dalam pengembangan sistem informasi penjualan retail pada toko Pacific Motor Bukittinggi yaitu Business Process Model Notation (BPMN), use case, sequence diagram, class analysis, class diagram, dan Entity Relationship Diagram (ERD).

3. Dalam membangun aplikasi, penulis menggunakan konsep Object Oriented Programming (OOP) dengan arsitektur Model-View-Controller (MVC). Proses pemrograman dilakukan dengan menggunakan bahasa pemrograman PHP pada sisi server dan menggunakan javascript, jQuery, Ajax pada sisi client untuk membangunan aplikasi berbasis web. Untuk pembangunan aplikasi mobile menggunakan bahasa pemrograman HTML dan Ajax dengan aplikasi pembangunan memakai Phonegap. Untuk database menggunakan PostgreSQL versi 9.2.

4. Pengujian sistem dilakukan dengan menggunakan metode blackbox testing untuk menguji fungsional sistem. Hasil pengujian menunjukkan bahwa sistem informasi penjualan retail sudah sesuai dengan kebutuhan fungsional dan dapat berjalan sebagaimana mestinya.

5. Aplikasi sistem informasi penjualan retail menunjukkan mobilitas yang tinggi dengan akses mobile memungkinkan pengguna untuk melihat informasi toko dimana saja dan kapan saja saat dibutuhkan 


\section{DAFTAR PUSTAKA}

[1] A. Darono, Aplikasi Excel sebagai Perangkat Bantu Audit, Jakarta: PT Elex Media Komputindo, 2007.

[2] Ferdiana and S. M. Ridi, Membangun Aplikasi SmartClient Pada Platform Windows Mobile, Jakarta: PT Elex Media Komputindo, 2008.

[3] A. F. Hanif, Analisis dan Perancangan Sistem Informasi Untuk Keunggulan Bersaing Perusahaan dan Organisasi Modern, Yogyakarta: Andi Offset, 2007.

[4] C. Dewi and K N. Pramono, Pembuatan Aplikasi Pencatatan Service Mobil di PT. Armada International Motor Berbasis Android, Jurnal Nasional Teknik Elekto dan Teknologi Informasi Universitas Gadjah Mada, Vol. 4, No. 4, November 2015, ISSN: $2301-4156$.

[5] R. S. Pressman, Software Engineering : A Practitioner Approach, McGraw-Hill Companies, 2011.

[6] K. D. Hartono, Implementasi Model View Controller dan Object Relational Mapping pada Content Manajemen Sistem Informasi Keuangan, http://repository.uksw.edu/handle/123456789/1329, 2009.

[7] Satzinger, Jackson, Burd. System Analisis and Design with the Unified Process. USA: Course Technology, Cengage Learning, 2010

[8] Evi Triandini, I Gede Suardika. Step by Step Desain Proyek Menggunakan UML. STIKOM Bali. Yogyakarta : Andi Offset. 2012.

[9] Irene, Herlinna Sectio. Entity Relationship Diagram (ERD) dan Contoh Kasus. 2014

Yani, Moren. Media Pembelajaran Matematika Untuk Balita Dengan Metode Glenn Doman Berbasis Android. Universitas Widyatama [10] Bandung: 2013 